\title{
Intensity of Judicial Review of the European Central Banks's Supervisory Decisions ${ }^{1}$
}

\author{
Andrea Magliari \\ University of Trento, Faculty of Law, Italy \\ andrea.magliari@unitn.it \\ https://orcid.org/0000-0002-5076-7176
}

Received: 30. 5. 2019

Accepted: 24. 7. 2019

\section{ABSTRACT}

A few years after the establishment of the Single Supervisory Mechanism, the General Court of the European Union, in its new supervisory role, annulled for the first time the decisions adopted by the European Central Bank (ECB). These judgments are of particular interest because they allow a preliminary investigation of the intensity of judicial review of the ECB's discretionary choices in the field of banking supervision. This article claims that the first case law of the General Court points to several interesting developments and indicates the resolve to carry out a judicial review which, although adhering strictly to the "limited review" standard, does not shy away from developing judicial techniques to ensure a more incisive scrutiny of the discretion enjoyed by the ECB. Despite the novelty of the issues brought to the attention of the EU judges, it seems possible as a result of this study to envisage, on the one hand, a gradual alignment of the scrutiny of supervisory decisions with those emerged in relation to the Commission's decisions on competition matters. On the other hand, a differentiation from the "light touch" approach adopted in the field of monetary policy can be observed.

Keywords: complex economic assessment, Court of Justice of the EU, European Central Bank, supervisory decisions, intensity of judicial review, leverage ratio, margin of discretion

JEL: K23

\section{Introduction}

A few years after the establishment of the Single Supervisory Mechanism (SSM), the General Court of the European Union annulled for the first time decisions adopted by the European Central Bank (ECB) within its new super-

1 The author wishes to thank Prof. Anna Simonati and the two anonymous referees for their helpful comments and constructive suggestions. Errors and omissions remain solely mine. 
visory role ${ }^{2}$. These judgments are of particular interest because they allow a preliminary investigation of the intensity of the judicial review of the ECB's discretion in the field of banking supervision.

As is well known, the SSM was introduced by Regulation (EU) no. 1024/2013 (the "SSM Regulation") as a response to the financial crisis of the Eurozone within the scope of the European Banking Union project (Chiti M.P. and Santoro, 2019; Lo Schiavo, 2019; Chiti E. and Vesperini, 2015). The SSM comprises a complex administrative system of banking supervision including the ECB as the responsible authority for ensuring the effective and consistent functioning of the Mechanism and the national supervisory authorities of the participating Member States. Notably, the ECB is endowed with a wide set of supervisory tasks and powers with a view to contributing to the safety and soundness of credit institutions in the Eurozone, as well as to the stability of the financial system within the Union.

In the performance of these tasks, the ECB is empowered to adopt legal measures directly addressed to private parties and capable of impacting their fundamental rights (Zilioli, 2017; Lamandini, Ramos Muñoz and Solana Álvarez, 2015). It becomes therefore essential to ensure that full and effective judicial protection is guaranteed to individuals in respect of such supervisory decisions. Among the various issues related to the judicial protection of the addressees of the ECB banking supervision (Chiti M.P., 2019; Cassese et al., 2018; Brescia Morra, 2016; Arons, 2015; Annunziata, 2019), little attention has so far been paid to the question of the intensity of judicial scrutiny on ECB supervisory decisions. Building upon the analysis of the first judgments of the General Court, the present article aims to contribute to the academic debate on the standards of judicial control of discretionary measures in the field of EU banking supervision.

\section{The issue of the intensity of judicial review in banking supervision: questions and methods}

The question of the intensity of the judicial scrutiny on the power of appraisal and on the complex technical assessments falling within the remit of EU administrative bodies has been widely debated by EU legal scholars (in particular, Craig, 2018, ch. 15; Schwarze, 2006; Baran, 2017; Fritzsche, 2010), especially with regard to the Court of Justice's review of European Commission decisions in matters of competition and state aid (da Cruz Vilaça, 2018; Derenne and Merola, 2012; Bailey, 2004; Kalintiri, 2016).

In this respect, it is well known that when EU bodies and institutions enjoy a wide margin of discretion, the Courts carry out a "marginal" rather than a "comprehensive" judicial review, in the sense that the latter is limited to verifying the observance of the procedural rules, the obligation to state reasons,

2 General Court of the European Union, section II (extended), 13 July 2018, Case T-733/16, La Banque postale v ECB; T-745/16, BPCE v ECB; T-757/16, Société générale v. ECB; T-751/16, Confédération nationale du Crédit mutuel v ECB; T-758/16, Crédit agricole SA v ECB; T-768/16, BNP Paribas v ECB. 
the material accuracy of the facts, and the absence of errors in law or manifest errors of assessment or misuse of powers (Prek and Lefèvre, 2019). Over the years, however, the EU judiciary has gradually refined its judicial review techniques, becoming less deferent to the margin of discretion conferred on the administration, albeit remaining formally anchored to a scrutiny that makes no attempt to substitute the Court's assessment for that of the public authority according to the formula of the "marginal" standard of review (Meij, 2009) ${ }^{3}$.

As noted above, the assignment of important executive tasks to the ECB in the field of banking supervision raises interesting questions that, given the absolute novelty of the SSM, have not yet been satisfactorily answered. A key question is whether the EU judges will apply the same standard of control to supervisory decisions as it has done to ECB's monetary policy measures, or whether the Court's review of eminently individual decisions addressed to single credit institutions or single persons will emulate the approach developed over time in the field of antitrust law. One may, in fact, wonder whether the EU judges will be ready to handle new and complex subject matters such as banking supervision and financial law, and whether they will gain the necessary expertise to carry out a thorough judicial review. Ultimately, it might well be asked whether - and on the basis of what itinerary - the EU judges will apply a judicial control that ensures in-depth appraisal of the discretionary choices made by the banking supervisory authority. These questions are of particular relevance since banking supervision involves both complex technical assessments and policy considerations: the former underpins the substantive rules applied by the supervisor; the latter is embedded in the need to balance divergent interests (public and private, national and supranational) throughout the decision-making process. Indeed, one may argue that the ECB's power of appraisal is not limited to conducting a purely objective - and as such neutral - assessment of technical and legal prerequisites, as it also encompasses a wider lato sensu political dimension, as expressly recognised by Article 127(6) TFEU, which lays down that the ECB may be assigned "specific tasks [...] concerning policies relating to the prudential supervision of credit institutions".

As is known, EU law does not clearly distinguish between "administrative discretion" (or discretion proper) and "technical discretion". While such distinction is well established in some Member States, like Germany and Italy ${ }^{4}$ (Bachof, 1955; de Pretis, 1995), in the EU the two dimensions are commonly understood as part of the general phenomenon of the freedom of choice/ appraisal left to decision-makers in the enforcement of EU law by a higherranking legal source. Both types of discretion are indeed treated as a homogenous concept and made subject to the same "marginal" standard of judicial review (Schwarze, 2006). In fact, although EU Courts make use of different ex-

3 A more incisive judicial review of decisions on concentrations was initially tackled by the Court of First Instance in the well-known Cases T-342/99, Airtours v Commission; T-310/01, Schneider Electric $v$ Commission and T-5/02, Tetra Laval v Commission, this latter decision subsequently confirmed by the Court of Justice, C-12/03 P, Tetra Laval, 15 February 2005.

4 This distinction is a feature of German law, which makes a distinction between "Ermessen" and "unbestimmter Rechtsbegriff", as well as of Italian law, distinguishing between "discrezionalità amministrativa" and "discrezionalità tecnica". 
pressions, such as "margin of appraisal", "power of appraisal" and "margin of discretion", one may argue that they do not attach any distinct consequence to each of them. Even in EU legal scholarship, there seems to be no consensus on such distinction (Prek and Lefèvre, 2019; Mendes, 2017; Bouveresse, 2010; Caranta, 2008; Schwarze, 2006). However, it is argued that the EU judicature should make the effort to develop a more analytical approach to the subject, by acknowledging different forms and intensities of "discretion" and, based on this, deriving different strategies of judicial review.

It is certainly beyond the scope of this article to elaborate a general theory on discretion in EU law. It is submitted, however, that the case law stemming from the new ECB supervisory tasks, given the particular intertwining of technical elements and policy evaluations, could actually contribute to the elaboration of a more structured judicial review of discretionary choices of EU bodies and institutions.

Against this background, the present article argues that the first General Court case law points to several interesting developments, as it indicates the Court's resolve to carry out a judicial review which, while adhering to the "limited review" standard, does not shy away from developing judicial techniques to ensure a more incisive scrutiny of the discretion enjoyed by the ECB, especially when it comes to checking its technical assessments.

\section{The leverage ratio and the French "livret a" judgments: preliminary results from the first case law}

A brief summary of the case which led to the annulment of the ECB decisions is useful for a better understanding of the General Court's reasoning, as well as for providing evidence of the complex interweaving of technical assessments and policy considerations.

In the years preceding the financial crisis, many credit institutions funded a substantial percentage of their investments through loans. With the advent of the crisis, however, severe losses and funding difficulties led to excessive exposures compared to equity, with the result that many credit institutions were forced to make hasty sales of some of their assets in order to reduce their exposures.

It was within this framework that Regulation no. 575/2013 (the Capital Requirements Regulation, or (RR) introduced a new prudential regulatory tool, the leverage ratio, as a further measure to add to the requirements established by the Basel II rules ${ }^{6}$. More specifically, Art. 429(2) CRR provides that "the leverage ratio shall be calculated as an institution's capital measure di-

5 Regulation (EU) No. 575/2013 of the European Parliament and of the Council of 26 June 2013 on prudential requirements for credit institutions and investment firms.

6 The "leverage" is defined in Art. 4(1)(93) CRR as "the relative size of an institution's assets, off-balance sheet obligations and contingent obligations to pay or to deliver or to provide collateral, including obligations from received funding, made commitments, derivates or repurchase agreements, but excluding obligations which can only be enforced during the liquidation of an institution, compared to that institution's own funds". 
vided by the institution's total exposure". A notable feature of this tool is that the leverage ratio is not calculated according to the riskiness of the institution's investments, but rather aims to give a "snapshot" of its leveraged investments (i.e. exposures) ${ }^{7}$. By way of derogation, Commission Delegated Regulation $2015 / 62$ on leverage ratio ${ }^{8}$ introduced the possibility of waiving this method of calculating the leverage ratio; paragraph 14 of Art. 429 CRR establishes that the competent authority may authorise the credit institution to exclude certain exposures to public bodies from its ratio calculation under certain circumstances.

In the case in question, six French credit institutions coming under the direct supervision of the ECB had applied to benefit from the exemption under Art. 429 CRR and exclude from the calculation certain exposures connected to savings accounts, such as the Livret $A$ (savings account $A)^{9}$, underwritten by investors at their premises, on the grounds that the French Code monétaire et financier required a certain percentage of these deposits to be transferred to the Caisse des dépôts et consignations (CDC), a French public financial institution.

The ECB rejected the six applications with six separate decisions stating that, although the exposures met the conditions mentioned in Art. 429(14) CRR, the supervisor was empowered with a margin of discretion that allowed it to refuse exemption on grounds of the risk regarding the safe and sound management of the supervised entity. In particular, the ECB considered that the mechanism by which assets were transferred by the CDC to the credit institutions was imperfect and raised prudential concerns as to the credit institutions' capital adequacy such as to justify the inclusion of the Livret A exposures in the calculation of the leverage ratio.

The six French credit institutions sought annulment of the ECB decisions before the General Court under Art. 263 TFEU. The applicants claimed that, firstly, the ECB had erroneously interpreted the relevant legislation, since Art. 429(14) CRR grants the supervisory authority power to ascertain the existence of the prerequisites established by the Regulation, but not the power to make discretionary decisions thereto, and, secondly, that the ECB had committed both an error of law and a manifest error of assessment in the interpretation and application of its power of waiver.

On the first claim, the Court confirmed the interpretation favoured by the ECB. In the view of the Court, the supervisory authority's power to exercise discretion in its decisions derives not only from the wording of the provision but also from its systematic and teleological interpretation. As already evidenced in Crédit mutuel Arkéa v ECB ${ }^{10}$, the CRR Regulation sets out three dif-

7 Recitals no. 90 et seq. of the CRR.

8 Commission Delegated Regulation (EU) 2015/62 of 10 October 2014 amending (EU) Regulation no. 575/2013 of the European Parliament and Council with regard to the leverage ratio.

9 The matter concerned especially Livret A, regulated by Arts. L.221-1 to L.221-9 of the Code monétaire et financier (CMF), livret d'épargne populaire (LEP), regulated by Arts. L.221-13 to L.221-17-2 of the CMF, and livret de développement durable et solidaire (LDD), as per Arts. L.221-27 of the CMF.

10 EU General Court, judgment of 13 December 2017, Case T-712/15, Crédit mutuel Arkéa v ECB, paras. 67 et seq. regarding application of Art. 10(1) CRR. 


\section{Andrea Magliari}

ferent scenarios in which an exemption provision can be implemented: in the first, the waiver is automatic as it descends directly from the law, without the intervention of the administration; in the second, before granting a waiver the supervisor must ascertain the existence of a series of prerequisites in a situation of "circumscribed powers"; and in the third, the derogation is subject not only to the existence of specific prerequisites but also to the discretionary judgement of the supervisory authority.

The Court ruled that the controversial provision must be traced to the last scheme and interpreted as granting the prudential authority discretionary power to choose and weigh up the different aims underpinning the substantive rule governing the leverage ratio.

It was therefore the task of the supervisor to identify the right balance between two diverging interests: on the one hand, the need to have a comprehensive overview of the indebtedness of each credit institution and, on the other, the opportunity to take into account effectively low-risk exposures, such as specialised lending to public sector entities, that are not the result of independent investment decisions by the credit institution.

Against this background, the Court proceeded to examine the second group of complaints by conducting an in-depth scrutiny of the reasons stated by the $\mathrm{ECB}^{11}$. First, the ECB had considered the accounting treatment of the regulated savings, noting that credit institution's exposures to that public financial institution were booked as liabilities in the institution's accounts whereas the amounts transferred to the CDC were registered in the assets. As a result, the ECB had concluded that the credit institutions bore the operational risk linked to the savings in question. In addition, the supervisor held that the credit institutions remained under a contractual obligation to reimburse customers of any sums deposited, regardless of the amounts transferred to the CDC, even in the event of default of the French state.

The Court held that the ECB refusal was based on considerations which were inherent in the exposures concerned by the exemption provision, and that the ECB's interpretation had the effect of rendering such derogation de facto inapplicable. Moreover, the Court underlined that the likelihood of the French State defaulting did not seem to have been either assessed or even taken into adequate consideration by the ECB. As a result, the decision to deny the benefit of Art. 429(14) amounted to an error of law since it was based on an

11 One may argue that the ECB could have raised an exception of illegality pursuant to Art. 277 TFEU regarding Art. 429(14) CRR, as introduced by the above-mentioned Delegated Regulation 2015/62. Indeed, some concern might be raised as to the legitimacy of this provision in terms of its compliance with Art. 290 TFEU, which states that delegated acts "supplement or amend certain non-essential elements of the legislative act". It may in fact be asked whether, by introducing a derogation to the CRR with regard to the comprehensive rationale underpinning the leverage ratio, the exemption in question impacts an essential element of Art. 429 CRR. Furthermore, the CRR does not seem to contain any provision attributing power of waiver to the delegated act. 
interpretation of the provision that disregarded the aims underpinning the introduction of the waiver, thereby depriving it of any practical effect ${ }^{12}$.

Finally, the ECB had ruled that the period for the adjustment of the credit institution's positions with those of a public financial institution risked generating higher leverage ratios that might oblige the banks to sell off assets to cover the interim deficit before the transfer of funds by the CDC. The appropriateness of this reasoning was closely scrutinised by the General Court. First, the Court noted that leverage ratio risks occur when a credit institution possesses insufficient liquidity. In such circumstances, a credit institution might be obliged to take measures not contemplated in its business plan, including the forced sales of its assets, in order to ensure higher liquidity. The Court noted, however, that the ECB decisions regarding the applicants' liquidity ratio, adopted only a short time before the contested decisions, acknowledged that the adjustment period did not constitute a liquidity risk, owing to the existence of a guarantee by the central government of a Member State and the short duration of the period between the outflows and inflows. The Court therefore concluded that the ECB's arguments stood in contrast to previous assessments of the ECB and, thus, based merely on a petitio principii.

In its conclusions, the Court also noted that the adjustment period might impact the leverage ratio only in the event of a "bank run", a situation typical of circumstances of extreme stress. However, the ECB had failed to carry out an in-depth examination of the characteristics of the regulated savings and had not assessed the likelihood of the bank run event ever taking place. As a result, the supervisory authority had failed in its duty to make a thorough and impartial examination of all the elements of the case and had adopted a manifestly erroneous decision.

\section{Discussion: the intensity of the judicial review of ECB supervisory decisions}

The General Court annulled the contested decisions because the ECB made an erroneous use of its discretion. According to the General Court, the ECB had erroneously interpreted the exemption provided for by Art. 429(14) CRR and, subsequently, unreasonably excluded its application on grounds incompatible with the underlying aim of the provision. The Court's reasoning can be broken down into two parts.

First, the Court assessed the correctness of the interpretation of the legal provisions governing leverage ratio, with regard to their rationale and scope of application. In that respect it is well known that, under Article 19 TEU, EU judges must ensure that, in the interpretation and application of the Treaties, EU law is observed. Accordingly, the administration does not enjoy a margin of discretion when interpreting EU law. The ECJ has the duty to carry out a

12 See also Case C-256/15, Nemec, paras. 48 and 49; C-407/07, Stichting Centraal Begeleidingsorgaan, para. 30; C-8/01, Taksatorringen, para. 62, where the Court of Justice made it clear that a provision containing an exemption may not be interpreted in such a restrictive manner as to deprive it of any practical effect, namely render it inapplicable. 
full review of the interpretation favoured by the administration and, if it disagrees, the Court can substitute its interpretation for that of the administration (P. Craig, 2010, p. 400).

These judgments confirm that the ECB, just like the other EU institutions, does not enjoy an autonomous margin of appreciation in matters of law interpretation. The interpretation of the relevant legislation by an administrative authority cannot bind the EU courts, which have exclusive jurisdiction to interpret EU law even vis-à-vis discretionary powers ${ }^{13}$. This holds true even if the decision under scrutiny involves the interpretation of complex economic elements and their legal qualification. According to the EU settled case law, factual elements might also come under the comprehensive review of the Courts in so far as their assessment is functional to the interpretation of a legal provision (Vesterdorf, 2005; Kalintiri, 2016) ${ }^{14}$. As the Court stated "whilst, in areas giving rise to complex economic assessments, the Commission has a margin of discretion with regard to economic matters, that does not mean that the Courts of the European Union must refrain from reviewing the Commission's interpretation of information of an economic nature" ${ }^{15}$.

A closer look at the Court's reasoning reveals that a similar test was applied in the case under examination. The Court, while scrutinising the ECB's interpretation of the waiver set out in the CRR, also assessed the factual elements and the economic evaluations underpinning such interpretation, concluding that the reasons stated by the ECB had the effect of rendering the legal provision de facto inapplicable.

The second step of the Court's reasoning involved judicial review of the discretion exercised by the ECB in the application of the substantive legal provisions. On this point, the Court referred to the usual "limited standard of review" formula. It is settled case law that when a contested decision has been adopted in the exercise of a power of appraisal implying a wide margin of discretion, the Court's review cannot substitute assessments coming within the remit of the administration, but rather must confine itself to ascertaining that the contested decision is not based on materially incorrect facts or vitiated by an error of law, manifest error of appraisal or misuse of power ${ }^{16}$.

Accordingly, the Court did not rule on the prevalence of one interest (rectius: prudential objective) over another and limited itself to identifying the existence of elements revealing the incorrect exercise of the ECB's power of appraisal starting from a careful examination of the reasons stated. In other words, the Court did not interfere with the "discretion proper" of the ECB,

13 See, most recently, Crédit mutuel Arkéa v ECB, para. 75.

14 See, in particular, Case C-42/84, Remia, para. 34; Case C-382/12 P, MasterCard and Others V Commission, para. 155; Case C-386/10 P, Chalkor v Commission, para. 62; Case T-286/09, Intel v Commission.

15 See Case C-272/09 P, KME Germany and Others v Commission, para. 94; Case C-389/10 P KME Germany and Others v Commission, paragraph 121; Case C-386/10 P Chalkor v Commission, para. 54.

16 See, ex multis, Case 42/84, Remia; Case T-115/99, SEP v Commission, para. 34; Case T-427/08, CEAHR v Commission; Case T-342/11, CEEES et Asociación de Gestores de Estaciones de Servicio V Commission. 
i.e. "its capacity to take policy decisions linked to the weighing of conflicting private and public interest" (Caranta, 2008, p. 195).

Instead, the manifestly erroneous nature of the contested decision has been inferred from the way the ECB assessed the relevant circumstances within the exercise of a technical appraisal. Such control has been conducted on the ground of compliance with the general principles and procedural guarantees of EU administrative law. It is well established in the EU case law that general principles count among the most powerful grounds for scrutinising EU discretionary decisions (Tridimas, 2006). It is no surprise, therefore, that scrutinising the reasons stated by the authority allowed investigation of the logical and legal correctness of the final decision, as well as an in-depth appraisal of the discretionary content of the contested measure (Hofmann and Rowe and Türk, 2011; Simonati, 2009).

The Court indeed recalled the well-known Technische Universität München jurisprudence (Court of Justice, 21 November 1991, Case 269/90, para. 14), according to which: "where a Community institution has a wide discretion, the review of observance of certain procedural guarantees is of fundamental importance" ${ }^{17}$. Moreover, reference has been made to the principle of sound administration according to which the competent institution has the duty to examine carefully and impartially all the relevant aspects of the individual case (Nehl, 2009; Azoulai and Clement-Wilz, 2014). The EU judicature did not confine itself to reviewing the formal and procedural legality of the challenged decision, according to the "process-oriented review" approach (Lenaerts, 2012), but also examined whether all the pertinent elements had been accurately and impartially considered, and whether the decision contradicted previous decisions.

Even though the Livret A judgments do not seem to follow the usual "light touch" approach, it is submitted that the General Court did not go so far as to step over the ECB's margin of appraisal. In other words, the CJEU did not substitute the ECB's findings with its own independent assessment of the factual circumstances, for example, by pointing out the unlikelihood of France defaulting or the imminent "run on the bank".

In sum, the annulment of the contested decisions was posited, on the one hand, on the wrong interpretation of the relevant legal provisions and, on the other, on the manifestly erroneous nature of the ECB's assessments. While in the scrutiny of the former the Court stuck with the "full review" standard, the manifest error of assessment was subject to the "limited review" test. The General Court indeed did not encroach on the ECB's discretion either by conducting an autonomous and alternative balancing of interest test, or by venturing into the re-assessment of the complex economic appraisals underpinning the contested decisions.

17 Similarly, ex multis, Case C-525/04 P, Spain v Lenzig, para. 58; Joined Cases C-258/90 and C-259/90 Pesquerias De Bermeo and Naviera Laida v Commission, para. 26. 


\section{Andrea Magliari}

A closer look at the judicial reasoning reveals, however, the General Court's willingness to carry out an in-depth control of the discretionary choices of the ECB. This is particularly true vis-à-vis technical appraisals (or "technical discretion") as the Court tends to blur the (not always clear) distinction between control over the interpretation of law on the one hand, and control over the application of the legal rules to the facts of the case on the other. In a highly regulated matter such as banking law, this allows a particularly thorough scrutiny over individual supervisory decisions, but at the same time may soften the distinction between "full" and "limited" judicial review ${ }^{18}$.

Another recent judgment of the General Court provides interesting indications about the intensity of judicial review on discretionary choices of the $E C B$, notably on the scrutiny of complex economic and technical assessments. In Crédit mutuel Arkéa v ECB, the ECB ordered a French credit institution to hold additional capital as a result of the Supervisory Review and Evaluation Process (SREP) pursuant to Art. 97 of Directive (EU) 2013/36 (the so-called CRD IV). The issue at stake was the assessment of the existence of prudential risks such that the sound management and the risk coverage by the credit institution could not be ensured ${ }^{19}$. The risk derived, in particular, from the likelihood of the credit institution leaving the Crédit mutuel group, a possibility surmised on account of an ongoing internal conflict within the group.

On examining the claim that the ECB had committed an error of assessment, the Court recalled the traditional formula of "limited" or "marginal standard of review", whereby "in the case of complex assessments, the EU authorities enjoy, in some areas of EU law, a broad discretion, so that review by the EU judicature of those assessments must necessarily be confined to verifying whether the rules on procedure and on the statement of reasons have been complied with, whether the facts have been accurately stated and whether there has been any manifest error of assessment or misuse of powers" 20 .

Nonetheless, the Court's decision was made on the basis of the stricter test developed in the competition and antitrust sector, starting from the wellknown Tetra Laval ruling. In other words, the Court deemed that "not only must the EU Courts establish whether the evidence relied on is factually accurate, reliable and consistent but also whether that evidence contains all the information which must be taken into account in order to assess a complex situation and whether it is capable of substantiating the conclusions drawn from it"21.

18 See the Opinion of A. G. Mengozzi in Case C-382/12 P, MasterCard, para. 119, claiming that this approach "has in itself the potential to neutralize de facto the very principle of the recognition of a margin of economic assessment to the Commission".

19 These measures were adopted pursuant to Art. 16(1) letter c), and Art. 16(2), letter a) of the SSM Regulation.

20 Arkéa, cit., para. 178.

21 Arkéa, cit. para. 179. Similarly, ex multis, Case C-295/12 P, Telefónica v Commission, para. 54; Case C-386/10 P, Chalkor v Commission; Case C-326/05 P Industrias Químicas del Vallés v Commission, para. 76; Case C-525/04 P, Spain v Lenzig, para. 57; Case C-12/03 P, Commission v Tetra Laval BV, рага. 39. 
Although not substituting the ECB's evaluation of the bank's risk profile, the Court did in fact proceed to assess individual facts and circumstances that revealed the existence of a conflict between the institution and the group, concluding that any split from the group did not appear so improbable as to vitiate the supervisor's decision on the grounds of a manifest error of assessment.

In conclusion, in this case, too, the Court did not substitute the ECB's assessment, nor did it go so far as to express a view independent from that of the administration. However, this judgment further confirms our first impression that, at least in principle, the EU judges seem ready to conduct an in-depth appraisal of the ECB's discretionary choices, examining the reliability of the factual elements underpinning supervisory decisions, even vis-à-vis complex economic assessments.

\section{Conclusions}

The Court rulings examined above allow us to draw a few preliminary conclusions regarding the intensity of judicial review of ECB supervisory decisions. The first case law seems to indicate that the EU courts intend to adopt an approach that goes beyond mere verification of the formal and procedural legality of a decision and to scrutinise more closely the administration's discretion, understood both as "discretion proper" and as "technical discretion" (on this unclear distinction in EU law, Prek and Lefèvre, 2019; Caranta, 2008; Schwarze, 2006).

Notably, the Court has not failed to conduct a full judicial review on questions of law, substituting its own interpretation for that made by the administration. This is of fundamental importance in a highly regulated sector like banking law, where the discretionary powers of the supervisory authority are often subject to prior assessment of several technical prerequisites precisely defined by the legislator. At the same time, this leads to the risk that the Courts will also apply a full judicial review with regard to the technical assessments carried out by the supervisor, thereby encroaching on its margin of (technical) discretion.

The judgments reviewed also confirm the propensity of EU judges to set great store by respect for procedural principles and guarantees as a means of ascertaining the correct exercise of administrative discretion. Even when considering the administration's power of appraisal in technical sectors, the Court seems to be adopting a more incisive attitude when assessing whether the evidence brought by the administration is reliable, plausible and consistent.

In these terms, despite the new subject matter coming before the EU Courts, the judicial review of ECB decisions appears to be aligning with the more consolidated approach adopted to examine Commission decisions in competition law and state aid. Not only does this approach meet the fundamental requirement to provide effective safeguards to individuals whose fundamental rights may be infringed upon by supervisory decisions, it also meets the need to "coun- 
ter-balance the far-reaching discretionary powers of the executive" (Schwarze, 2004) and to support the legitimation and accountability of the supervisor.

These observations allow us to make a more general assumption as to the intensity of judicial review the EU Courts will apply vis-à-vis the acts adopted by the ECB. The EU Courts are known to pursue a "flexible judicial review strategy" (Schwarze, 2004), calibrated to the features of each single case and the nature of the power exercised. It would therefore not be unreasonable to assume that, in principle, the intensity of judicial review of ECB acts will vary depending on whether the subject matter falls within the sphere of monetary policy or banking supervision (Zilioli, 2017; Lehmann 2017). The EU Courts might be expected to continue to adopt a deferent "light touch" approach to monetary policy matters, in line with the Gauweiler Case ${ }^{22}$ and, more recently, the Weiss Case ${ }^{23}$ (Tridimas and Xanthoulis, 2016; Goldmann, 2014). There are several reasons for this: the wide institutional mandate enjoyed by the ECB in pursuing the objective of price stability; the exquisitely lato sensu political nature of monetary measures, requiring a careful balancing of different interests; the fundamental need to preserve the stability and reliability of monetary decisions; and finally, the infungible nature of the macroeconomic assessments carried out by the monetary authority.

Conversely, judicial review of supervisory decisions is likely to be more intense, especially when these decisions are addressed to individuals and do not have regulatory effects. In these cases, the ECB acts as a purely administrative authority and the Court of justice functions as an administrative judge (Bertrand, 2015) in charge of protecting individuals' fundamental rights, such as the right to property or the freedom to conduct a business, rather than a constitutional court. Its activity does not always involve value judgments or policy decisions, as it is often bound by a detailed set of procedural and substantive rules.

In that respect, a differentiated scrutiny involving varying standards of review for different kinds of actions should be adopted. Accordingly, a further differentiation could be made between, on the one hand, supervisory measures having a general scope (such as regulations, general instructions and guidelines) or decisions involving a discretionary weighing up exercise of different interests (discretion proper) and, on the other, decisions in mere application of legal provisions (circumscribed powers) or, at most, based exclusively on highly technical assessments (technical discretion). In the latter two cases, the need to preserve the supervisory authority's margin of appraisal appears less pressing, while of utmost importance is ensuring individuals full and effective judicial protection.

22 Court of Justice, Case C-62/14, Gauweiler and other, otherwise known as OMT Case.

23 Court of Justice, Case C-493/17, Weiss and others. 


\section{References}

Annunziata, F. (2019). Fostering Centralization of EU Banking Supervision Through Case-Law. The European Court of Justice and the role of the European Central Bank. Bocconi Legal Studies Research Paper Series, Bocconi University.

Arons, T.M.C. (2015). Judicial protection of supervised credit institutions in the European Banking Union. In D. Busch and G. Ferrarini (eds.). European Banking Union. Oxford: Oxford University Press.

Azoulai, L. and Clement-Wilz, L. (2014). La bonne administration. In J.-B. Auby and J. Dutheil de la Rochère (eds). Droit administratif européen. Bruxelles: Bruylant.

Bachof, O. (1955). Beurteilungsspielraum, Ermessen und unbestimmter Rechtsbegriff im Verwaltungsrecht. JuristenZeitung, 1955, pp.97-102.

Baran, M. (2017). The scope of EU Courts' jurisdiction and the review of administrative decisions - The problem of intensity control of legality. In C. Harlow, P. Leino and G. della Cananea, eds. Research Handbook on EU Administrative Law. Cheltenham-Northampton: Edward Elgar.

Bailey, D. (2004). Scope of Judicial Review under Article 81 EC. Common Market Law Review, 41, pp. 1327-1360.

Bertrand, B. (2015). Le juge de l'Union européenne, juge administrative. Bruxelles: Bruylant.

Bouveresse, A. (2010). Le pouvoir discrétionnaire dans l'ordre juridique Communautaire. Bruxelles: Bruylant.

Brescia Morra, C. (2016). The administrative and judicial review of decisions of the ECB in the supervisory field. In Scritti sull'Unione Bancaria. Quaderni di Ricerca Giuridica della Banca d'Italia, No. 81.

Caranta, R. (2008). On Discretion. In S. Prechal and B. van Roermund, eds. The Coherence of EU Law. The Search for Unity in Divergent Concepts. Oxford: Oxford University Press, $214 \mathrm{p}$.

Cassese et al. (2018). Judicial review in the Banking Union and in the EU financial architecture. Quaderni di Ricerca Giuridica della Banca d'Italia, no. 84.

Chiti, M.P. and Santoro, V. (eds.) (2019). The Palgrave Handbook of European Banking Union Law. Basingstoke: Palgrave Macmillan.

Chiti, M.P. (2019). The European Banking Union in the Case Law of the Court of Justice of the European Union, in M.P. Chiti and V. Santoro, eds., The Palgrave Handbook of European Banking Union Law. Basingstoke: Palgrave Macmillan.

Chiti E. and Vesperini, G. (eds.) (2015). The Administrative Architecture of Financial Integration. Institutional Design, Legal Issues, Perspectives. Bologna: Il Mulino.

Craig, P. (2018). EU Administrative Law. Oxford: Oxford University Press.

Craig, P. (2010). Judicial review and questions of law: A comparative perspective. In S. Rose-Ackerman and P.L. Lindseth, eds. Comparative Administrative Law. Cheltenham: Edward Elgar.

da Cruz Vilaça, J.L. (2018). The intensity of judicial review in complex economic matters - recent competition law judgments of the Court of Justice of the EU. Journal of Antitrust Enforcement, 6(2), pp. 173-188.

de Pretis, D. (1995). Valutazione amministrativa e discrezionalità tecnica. Padua: CEDAM.

Derenne, J. and Merola, M. (eds.) (2012). The Role of the Court of Justice of the European Union in Competition Law Cases. Bruxelles: Bruylant. 


\section{Andrea Magliari}

Fritzsche, A. (2010). Discretion, scope of judicial review and institutional balance in European law. Common Market Law Review, 2010, 47(2), pp. 361-403.

Goldmann, M. (2014). Adjudicating Economics? Central Bank Independence and the Appropriate Standard of Judicial Review. German Law Journal, 15, p. 265.

Hofmann, H.C.H, Rowe, G. and Türk, A. (2011). Administrative Law and Policy of the European Union. Oxford: Oxford University Press.

Kalintiri, P. (2016). What's in a name? The marginal standard of review of 'complex economic assessments' in EU competition enforcement. Common Market Law Review, 53, pp. 1283-1316.

Lamandini, M., Ramos Muñoz, D. and Solana Álvarez, J. (2015). Depicting the limits to the SSM's supervisory powers: The Role of Constitutional Mandates and of Fundamental Rights' Protection. Quaderni di Ricerca Giuridica della Banca d'Italia, no. 79.

Lehmann, M. (2017). Varying standards of judicial scrutiny over central banks actions. ECB Legal Conference 2017: Shaping a new legal order for Europe: a tale of crises and opportunities, 4-5 September 2017, Frankfurt am Main.

Lenaerts, K. (2012). The European Court of Justice and Process-Oriented Review. Yearbook of European Law, 31, pp. 3-16.

Lo Schiavo, G. (ed.) (2019). The European Banking Union and the Role of Law. Cheltenham: Elgar Financial Law series.

Meij, A. (2009). Judicial Review in EC Courts: Tetra Laval and Beyond. In O. Essens, A. Gerbrandy and S. Lavrijssen, eds. National Courts and the Standards of Review in Competition Law and Economic Regulation. Amsterdam: Europa Law Publishing.

Mendes, J. (2018). Bounded discretion in EU law: A limited judicial paradigm in a changing EU. Modern Law Review, 80, pp. 443-472.

Nehl, H.P. (2009). Good administration as procedural right and/or general principle? In H.C.H. Hofmann and A. Türk, eds. Legal Challenges in EU Administrative Law. Towards an Integrated Administration. CheltenhamNorthampton: Edward Elgar.

Prek, M. and Lefèvre, S. (2019). "Administrative discretion", "power of appraisal" and "margin of appraisal" in judicial review proceedings before the General Court. Common Market Law Review, 56, pp. 339-380.

Schwarze, J. (2006). European Administrative Law. London: Sweet \& Maxwell.

Schwarze, J. (2004). Judicial Review of European Administrative Procedure. Law and Contemporary Problems, pp. 85-106.

Simonati, A. (2009). Procedimento amministrativo comunitario e principi a tutela del privato. Padova: CEDAM.

Tridimas, T. (2006). The General Principles of EU law. Oxford: Oxford University Press.

Tridimas, T. and Xanthoulis, N. (2016). A Legal Analysis of the Gauweiler Case. Maastricht Journal of European \& Comparative Law, 23, pp. 17-39.

Vesterdorf, B. (2005). Standard of proof in merger cases: Reflections in the light of the recent case law of the Community Courts. European Competition Journal, 1, pp. 3-33.

Zilioli, C. (2017). Justiciability of central banks' decisions and the imperative to respect fundamental rights. ECB Legal Conference 2017: Shaping a new legal order for Europe: a tale of crises and opportunities, 4-5 September 2017, Frankfurt am Main. 